\title{
Perceptions of EFL teachers towards using intercultural approach in ELT
}

Arjun Singh Negi

Assistant Professor, Far Western University, Central Campus, Mahendranagar

\begin{abstract}
Teaching English has shifted from teaching literature to teaching language in cultural contexts. Teaching English in a cultural context improves intercultural competence but also needs to incorporate the local culture of the learners to enhance awareness and eliminate ethnocentricism. Intercultural approach tries to develop intercultural competence in the learners. Intercultural competence means following one's own culture and respecting others' cultural viewpoints. I have used phenomenological research design to find out perceptions of EFL teachers towards using intercultural approach in English language teaching. The finding indicates the need of practicing intercultural approach in English language teaching though the implementation is not quite easy. This research has also indicated that there is the hegemony of western culture in the course development and content selection. Still there are many problems in promoting local cultures and developing intercultural competence. To implement intercultural approach successfully, there should be radical changes in policy level, practice level, and pedagogical level, for the policy making, course development, content selection, classroom delivery and even in evaluation scheme.
\end{abstract}

Keywords: ELT, intercultural approach, EFL, intercultural competence

\section{Introduction}

An intercultural approach to second language acquisition draws upon a range of intellectual traditions to explore the cultural contexts of language and of language learning. Although some learners acquire another language for quite specific and limited purposes, increasingly we adapt our language and learn new ones under the pressures of migration and out of the need to reach a settlement with new contexts of communication. These new contexts are not simply contexts for language use but structured instances of a culture at work in all its richness and density. All these take place in specific contexts and in these contexts, cultures play as habitual patterns of interaction, routine forms of social practice, requirement frameworks of value and belief, as a dense backdrop, culture is implicated in every instance of language use. But if culture is a constant backdrop to the everyday use of language, how it is best 
to equip the learners with cultural knowledge? For a while any language as a code is finite, cultures are boundless and it is difficult to anticipate what features of contexts will be significant for communication.

The main purpose of intercultural approach to language teaching is to equip the learners with ways of analyzing and interpreting culture. Fundamentally, it provides the learner with methodologies for exploring cultural difference enabling them to explore their own culture as well as the target culture. The intercultural element of this kind of second language education also requires teachers and learners to pay attention to and respect the home culture and the home language. Learning materials have to incorporate aspects of the home culture, and non-native teachers become particularly valued for their own ability to move between the home and target cultures.

Although ELT has received extensive treatment in the literature regarding English in international contexts (Canagarajah, 2005; Jenkins, 2003), the cultural dimension has still to be fully explored. However, a consensus is beginning to emerge on the importance of skills and knowledge that go beyond the structure and vocabulary of a language and begin to address the importance of negotiation, adaptation, and accommodation in intercultural communication. Merely language structures and vocabulary are not enough to achieve the mastery in second language but the comparative analysis of the values of target culture and home culture with respect to both of them is still lacking. The purpose of my study is to find out perception of EFL teachers regarding the use of intercultural approach in teaching English as foreign language.

\section{Literature Review}

Many of the materials are produced in inner circle countries, usually by international publishing companies. Furthermore, the cultural references of English are often those of the inner circle with literature courses typically focusing on American and British literature and a course on the culture of the English speaking peoples' offered which also specifies inner circle countries as the cultures of interest. Underpinning much of this are models of grammar, pronunciation, rhetorical structures, discourse strategies and cultural forms and practices which are modeled on inner circle English speakers. In classrooms, 'home culture' of the learners can be exploited as a valuable classroom resource. This involves teachers finding out about students' production and consumption of cultural products- whether home culture in this sense means ethnic culture, class culture or professional culture. This can be 
done in class initially through questionnaires which can target specific topic areas (Murray et al. 1992, p.5). Questionnaires about language use in everyday life can serve as a starting point for learners and teachers to become more keenly aware of their own linguistic practices.

Some features of intercultural approach like cultural topics, acculturation, and cultural awareness-raising, reflective and critical eye are also found in previous communicative curriculum, however, the intercultural approach differs from earlier approaches to teaching culture by moving intercultural knowledge and skills, centre stage and making them an integral part of the curriculum. Intercultural communication takes place between participants with different cultural backgrounds or linguacultures and hence using different linguistic and discourse strategies (Muller-jacquier, 2004, p.45). Therefore, the relationship between English and English cultures in intercultural communication becomes problematic when there is no obvious target culture or cultural context for the language.

Another perspective on global uses of English and ELF is offered by Canagarajah's focus on the "local in the global" (2005, p. xvi). Drawing on Clifford's conception of "travelling cultures" (1992), Canagarajah views cultures in global contexts as hybrid, diffuse, and de-territorialized. English use and teaching needs to be understood from a perception of fluidity and mixing of languages, cultures and identities. Learners of English are not learning to join a single language community, but are." Shuttling between communities" (Canagarajah, 2005, p. xxvi), between the local and the global, in which a variety of norms and a repertoire of codes are to be expected. In focusing on the tensions between local and global contexts of use, Canagarajah, like Pennycock and Risager draws attention to the complex flow of linguistic and cultural practices through a global language such as English. This, Canagarajah proposes, should lead to a re- evaluation of the value of local knowledge and practices in English use and a move away from the hierarchical approach towards inner circle NES (Native English Speaker) expertise, especially in regard to second language education. There should be a focus on multilingual and multicultural communicative practices and on negotiation and communicative strategies. In the same line, Polzl and Seidlhofer follow a perception of ELF as a global means of communication that is locally realized, emphasizing that ELF users ," are not required to adopt the culture(s) associated with English as a native language," (2006, p.153) rather they emphasized in the discourse among different cultures. 
As language and culture are interrelated, intercultural awareness would be a relevant concept for English language teaching particularly in a global context. " By attempting to create learning situations that acknowledge the cultural aspect of language learning, second language instruction becomes more meaningful and makes a positive contribution to society by cultivating learners who appreciate cultural similarities and differences with experiences and perspectives of cultural diversity (Rappel, 2011).

Currently, culture has become a significant component of pedagogic theory in language (Byram, 1991). Tomalin and Stempleski mentioned the cultural context in discourse as," sensitivity to the impact of culturally -induced behavior on language use and communication" (1993, p.5). They highlighted three elements which they feel are necessary qualities of cultural awareness: awareness of our own culturally induced behavior; awareness of others' culturally induced behavior and the ideas. Therefore language teaching is not merely the presentation of its structures; it is interculturality that designates multiple way relationships, negotiations and cultural exchanges; " In other words, interculturality is not simply about recognizing, discovering, or tolerating the other and their differences ; nor about considering some identities as essential or immovable, in fact, it is a space for exchange, where encounters between individual's, knowledge, meanings, and different practices are built together. In the same way, intercultural competence is the ability to recognize, accept, and value one's own culture and the ability to establish self-identity while mediating between cultures. The extent to which individuals manifest aspects influenced by their cultural affiliations and characteristics is what makes interaction an intercultural phenomenon.

The implementation of intercultural approach and intercultural awareness activities should be taught through exploration, reflection, and discussion about one's own culture, target culture, and world culture (Corbett, 2010). For this reason, the appropriateness of language use and appreciation of similarities and differences of cultures are an integral part of intercultural awareness. Intercultural awareness can also be regarded as the foundation of communication and becomes essential when individuals communicate with people from other cultures (Zhu, 2011). It is important to develop intercultural awareness in English as a Foreign Language (EFL) instruction in order to help learners reach effective communication in intercultural settings. 
Intercultural communication is resulted from globalization in which people from different cultural backgrounds have to become increasingly dependent on one another in such a smaller world. Individuals can hardly avoid the interaction with people from different cultural backgrounds. When people communicate and establish relationships with those from different cultures, they learn more about other ways of life and this can lead to healthier communities, reduced conflict, and increased tolerance. (Neuliep, 2003).

A part of competence in foreign language is intercultural communicative competence, which Meyer (1991) defines as the ability of an individual to behave adequately and in a flexible manner when encountering with actions, attitudes, and expectations of people from foreign cultures. Adequacy and flexibility mean an awareness of the cultural differences between one's own culture and the foreign culture and the ability to handle the situation when cross-cultural problems occur. We need to have cultural knowledge and intercultural awareness before we achieve intercultural communicative competence. Intercultural awareness helps learners communicate across cultures in the current situation that English is used as the world language. If students can speak English well but still have only the perception of their own culture lacking awareness of other cultures, they will have some problems in getting along with or living with foreigners (Kim, 2002). Therefore, to make the communication successful, intercultural speakers should understand more than one social identity and national culture and so that they could be engaged in interaction with people from various cultural contexts. As a result, learners who have high intercultural awareness would be effective intercultural communicators.

\section{Methodology}

The purpose of this study is to explore the perceptions of the EFL teachers about intercultural approach in teaching. This is a qualitative research study with phenomenological research approach. Interpretivists understand the world through human experience. They try to explore the reality by analyzing participants' views, their backgrounds and experiences. In other words, interpretivism allows researchers perceive the world through the perceptions and experience of the participants. Therefore, I employed phenomenological research design to explore the perceptions of EFL teachers towards the use of intercultural approach in teaching English as a foreign language in Far Western University, Central Campus, Mahendranagar, Nepal. I used interview as the data collection tool and four faculty members who have been teaching in Central Campus of FWU for more than ten years at undergraduate level 
were selected as the participants by using judgmental sampling procedure. In depth interview was taken and data was collected. I used informal indepth interview to collect realistic information.

\section{Results and Discussion}

The collected data from the participant was recorded and transcribed. After the deep analysis of the data, it was organized into four different themes: importance of intercultural approach in EFL context, problems in teaching English through intercultural approach, teaching materials, use of pedagogy and future directions and implications. This study has presented that intercultural approach is the equal respect of learner's first language and second language cultures. Intercultural approach enriches the understanding and experiences of first language culture and target language culture interestedly. The subsequent section presents the discussions based on the information thematically.

\section{Importance of intercultural approach in EFL context}

Regarding the importance of intercultural approach in EFL context, teacher A said: It is a type of relationship between L1 and L2 cultures that promotes mutual understanding and respect of both of the cultures. It promotes adjustment, socialization, and social harmony. It promotes respect of both of the cultures. People at present are in contact of each other for various reasons like trade, business, tourism, diplomacy, sports, education and many other sectors. The world is becoming a global village and they are influenced by each others' cultures and languages. So it is urgent to have the knowledge of learners' first language culture and the target language culture.

The above mentioned lines have traced the importance of intercultural approach by showing the relationship between the learners' first language and target language. It further indicates that language should be perceived in its cultural aspects that promote adjustment, socialization, and social harmony among the speakers of different languages. We cannot understand language without understanding its cultural aspects. So it is important to understand different cultures and languages that makes communication successful and promotes adjustment, socialization and social harmony.

Emphasizing in the importance of intercultural communication, the teacher B has strongly mentioned: 
This is the era of globalization. People from various countries come in contact with each other for various purposes. If they know each other's cultures the communication can be successful. So it is important to integrate intercultural approach in EFL context. The contents in courses should be selected by giving equal priority to the learners' native language culture and different other cultures.

In the above lines, she has strongly emphasized in the importance of intercultural approach in this era of globalization. Different cultures should be given equal priority in syllabus designing and content selection so that learners are motivated in learning.

\section{Problems in teaching English through intercultural approach}

Regarding the problems in teaching English through intercultural approach, teacher A has expressed his dissatisfaction with the policy of syllabus designing and content selection as:

Most of the textbooks prescribed for undergraduate level in Far western university are filled with L2 culture only. They include the lessons from British, American or other target language cultures but no textbooks are related to the learners' native culture. Therefore, the contents for the learners are difficult to understand and demotivating. There is rarely the discussion of native culture of the students in the textbooks.

He further argued that: There is rarely the discussion of L1 culture in the classroom. Neither the teacher nor the students are interested to discuss about the naïve culture in the classroom as both of them are inclined to complete the course prescribed in the syllabus within allocated time. There are more than thirty students in average in undergraduate class so there is not enough time for discussion in the classroom. Except the prescribed textbooks there are rarely the materials available to the students.

In large classes teacher can not address the problems of different students, their interests, likes, and dislikes, norms and values. The attention of the teachers and students is mainly focused in the completion of the course within allocated time. As discussed above, the courses and textbooks are filled with the target language cultural values. There is the domination of western cultures in the content and the 
learners are also hegemonized that western cultures are superior to their native one. Western cultures, pronunciation, life style, literature all are the stereotypes for the rest of the world and they should be adopted without asking a question. Another misconception is that except the western culture the rest of the cultures are irrelevant to study English. This hegemony of western cultures is so powerful in the course designing, attitudes of experts, teachers, and students and even in societies. But it is not only the problem; the other problems are large classes where it is difficult to address the students' cultural values and ideologies. There are not sufficient materials available in English that carry on native cultures of the learners. There is not a clear policy to design the courses based on different cultures and intercultural perspectives. Highlighting the priority in content selection, material designing and classroom delivery, Teacher $\mathrm{C}$ declared:

There are rarely the texts with content of L1 culture. No discussion of culture, we discuss only language. Textbooks and other teaching materials are not enough and native culture is neglected in the course. There is problem in syllabus designing. Learners come from different cultures and they adopt different norms and values. So it is difficult to deal with the students in the classroom.

There is a great problem in pedagogy also. Textbooks or reading materials are filled with the content from target language, its culture, ideologies and literature. There are very few materials which design the content from various cultures in an integrated way. In the classrooms, teachers mainly focus on linguistics and grammar rather than its cultural aspects. But in real life communication, pragmatics, cultural aspect, assimilation of different cultures, comparison of different cultures etc are more important aspects than mere target language literature. Regarding the syllabus designing process, Teacher D has suggested:

There is problem in syllabus designing. Different cultures should be properly addressed in the course content. But target language culture is considered much important by the syllabus designers, textbook writers, teachers and students.

Teachers and students give less priority to their L1 cultures; they are less proficient in target language culture so there is always a gap between L1 and L2 culture. Textbooks and courses emphasize in target language culture with high priority, native speaker teachers are considered as superior as non native speaker 
English teachers. The syllabuses and courses do not give emphasis in comparison between first language culture and target language culture. Similarly there is no open discussion between first language culture and target language culture. On this issue, teacher A said:

Learners come from different cultural backgrounds and they adopt different norms and values. Overcrowded classroom is another problem in which because of the lack of resources teacher cannot address the problems of all students in the class. Respect of one culture sometimes means to disrespect of another one. Different students have different interests, likes, dislikes and preferences.

From this discussion, we come to know that in the classroom, there are the students from different cultural backgrounds; they follow different values and norms. When they communicate with each other they misunderstand each other as they have different interests, and preferences.

\section{Teaching materials}

Regarding teaching materials, Teacher B said:

Textbooks and other types of reading materials are not enough.

Teachers and students have ego problem. It means that they give

high priority to their own culture and they give less respect to other cultures. Texts mainly represent the target language culture and the issues of L1 culture are rarely addressed.

Institutions do not have enough facilities which can facilitate students to learn about other cultures. Textbooks and other reference materials are not enough. In prescribed textbooks and reference materials, there is domination of target language culture and rarely there is the reference of L1 culture. In this regard, teacher A said:

Because of the lack of proper use of technology like computer, internet etc they do not get the exposure of different cultures. In a class with many students, neither the teacher can address their individual problem nor can they be given opportunities to express their cultural values and ideals. It leads towards disagreement, frustration and conflict in the classroom. Due to poor internet facilities, students do not have opportunities to explore other people's cultures globally. 
The main cause of frustration of learners is the conflict between the L1 and L2 cultures. Technological facilities should be provided to the learners so that they could explore different cultures and develop mutual harmony towards them. The teacher D said:

The problem lies in curriculum and syllabus designing. Only target language culture is focused in designing syllabus and selecting texts. There is a gap between L1 culture and L2 culture. Textbooks give priority to target culture and teachers give priority to their own culture. As a result, students find themselves in confusion. Lack of exposure to visit different countries and meeting people from different cultural backgrounds, lack of fund and budget, lack of infrastructure, lack of resources, lack of discourse about different cultures are the key problems. The English language syllabus did not seem to address the inclusion of culture or cultural awareness to any degree.

The problem mainly lies in the syllabus designing and course development. Courses should be designed by giving equal priority in different cultures. The students should be exposed to various cultures by providing the opportunities of excursion tours physically and virtually.

\section{Future directions and implications}

Teacher C said:

Policy should be made to facilitate intercultural approach. Equal importance should be given to different cultures. Students should be developed as global citizens with intercultural awareness. In order to become culturally aware, one needs to be immersed in different cultures. Students should be given opportunities to share their cultures in the classroom. In place of deficit discourses, supportive discourses should be constructed by teachers about students. Students should be given opportunity to share their culture in the classroom. Cultural fairs and festivals can be organized.

To implement Intercultural Approach in English Language Teaching, we should change in classroom pedagogy also. We should implement culturally relevant pedagogy. It means that we should respect different cultures, compare and contrast different cultural values and address them appropriately. We should 
minimize traditional teaching methods and maximize modern techniques as role play, discussion, cultural show, and cultural sharing including intercultural fairs, and festivals. Regarding this issue, Teacher A mentioned:

Cultural tours should be organized. Values of different cultures should be mutually respected. Students should be given good environment so that they can enjoy learning. Content should be presented with equal emphasis to L1 and L2 cultures. In the same line Teacher B has also mentioned: Teachers should have open and critical point of view to deal with language and cultural related problems.

Teaching language should be considered as teaching culture. Mutual relation should be established among the people from different ethnicities, social groups, professions, genders etc. Mutual understanding should be developed among the people of same country or different countries. Curriculum or instructional materials should be properly designed. Language policy should be reformed to respect different cultures. Egoism, skepticism, frustration regarding different cultures and languages should be minimized. Language teachers should be developed as " reflective practitioners". There should be clear guidelines for teachers about language teaching in general and developing intercultural competence in particular. It is important to pay attention to the challenges of language teachers who must be prepared and competent to teach intercultural communicative competence. Education policy should focus in strengthening of discourses of mutual understanding, tolerance and intercultural dialogue by building the spaces for negotiation, peace and harmony among people. Holmes(2014, p.1) advocates," intercultural dialogue" is now in wide currency and offers much hope to peace and harmony among nations".

\section{Conclusion}

This research study concludes that the English teachers of Far Western University are found to be positive regarding the implementation of Intercultural Approach in English Language Teaching. Intercultural approach is very important in EFL situation as it promotes adjustment, socialization, and social harmony. The problem lies in content selection, lack of materials and proper classroom delivery. At policy level, the planners can design the course by assimilating the content from various cultures. Culturally relevant pedagogy should be developed and implemented. At present context, learners need to develop understanding and knowledge about other cultures and learn the values of mutual respect, tolerance and harmony. 


\section{References}

Baker, W. (2008). A Critical examination of ELT in Thailand : the role of cultural awareness. RELC, 39(1), 131-146.

Baker,W. (2009). Intercultural awareness and intercultural communication through English : an investigation of Thai English language users in higher education. (doctoral dissertation), University of Southampton.

Baker,W.(2012). From cultural awareness to intercultural awareness: culture in ELT. ELT journal, 66(1), 62-70.

Bakhtin, M. (1981a). The dialogic imagination (Holquist, M.,Trans.). Austin; Texas University Press.

Byram, M. and Grundy, P. (2003). Context and culture in language teaching and learning. Clevedon: Multilingual Matters.

Byram, M. (1991a). Investigating Cultural studies in foreign language teaching. Cleveden: Multilingual Matters.

Byram, M. (1991b). Teaching culture and language: towards an integrated model. In M. Byram and D. Buttjes, (Eds.), Mediating languages and cultures (pp.1732). Clevedon: Multilingual matters.

Byram, M. (1997). Teaching and assessing intercultural communicative competence. Multilingual Matters.

Byram, M. (2000). Assessing Intercultural Competence In language Teaching . Sprogforum, 6(18), 8-13.

Byram, M. (2008a). From foreign language education to education for intercultural citizenship: Essays and reflections. Clevedon : Multilingual Matters Ltd.

Canagarajah, A.S. (2005). Reclaiming the local in language policy and practice. Mahwah, N.J., London: L.Erlbaum Associates.

Corbett, J. (2010). Explore, reflect, and discuss: Intercultural activities for the language classroom. New Routes, 14-18.

Corbett, J. (2007). An intercultural approach to English language teaching. Clevedon: Multilingual Matters.

Jenkins, J. (2003). World Englishes: A resource book for students. London: Routledge. 
Kachru, Y., \& Smith, L.E. (2008). Cultures, contexts, and world Englishes. New York: Routledge.

Kim, J. (2002). Teaching culture in the English as a foreign language classroom. The Korea TESOL Journal, 5, 27-40.

Kramsch, C. (1998). Language and culture. Oxford: Oxford University Press.

Lustig, M. \& Koester, J.(2012). Intercultural competence: Interpersonal communication across cultures $\left(6^{\text {th }}\right.$. Ed.): Pearson.

Neuliep, J.W. (2003). Intercultural communication: A contextual approach $\left(2^{\text {nd }} \mathrm{ed}.\right)$. New York: Haughton Mifflin.

Nguyen, T. M. H. (2008). Developing EFL learners' intercultural communicative competence: A gap to be filled?. Asian EFL Journal 21 (July) 122-139.

Rappel, L. (2011). An analysis and interpretation of intercultural approaches to English language teaching. Journal of Integrated Studies, 1(2).

Risager, K. (2006). Language and culture: Global flows and local complexity. Clevedon: Multilingual Matters.

Yang, P. (2018). Developing TESOL teacher intercultural identity: An intercultural communication competence approach. TESOL Journal, 525-541. https: //doi. org/10.1002/tesj.356.

Zhou,Y. (2011). A study of Chinese university EFL teachers and their intercultural competence teaching University of Windsar. Retrieved from https.//scholar. uwindsor.ca/etd/428.

Zhu, H. (2011). From intercultural awareness to intercultural emphathy. English Language Teaching, 4(1),116-119. 